\title{
Korelasi antara Kadar Vitamin D dengan Kejadian Preeklamsi
}

\author{
Ekadewi Retnosari, ${ }^{1}$ Wiryawan Permadi, ${ }^{2}$ Elsa Pudji Setiawati, ${ }^{3}$ Farid Husin,,${ }^{4}$ Johanes C Mose, ${ }^{5}$ Udin Sabarudin ${ }^{6}$ \\ ${ }^{1}$ Mahasiswa Program Magister Kebidanan Fakultas Kedokteran Universitas Padjadjaran \\ ${ }^{2,5,6}$ Depertemen Obstetri dan Ginekologi Fakultas Kedokteran Universitas Padjajaran \\ ${ }^{3}$ Departemen Ilmu Kesehatan Masyarakat Fakultas Kedokteran Universitas Padjajaran \\ ${ }^{4}$ Departemen Epidemiologi dan Biostatistika Fakultas Kedokteran Universitas Padjadjaran
}

\begin{abstract}
Abstrak
Program Pembangunan Kesehatan di Indonesia dewasa ini masih diprioritaskan pada upaya peningkatan derajat kesehatan ibu dan anak, terutama pada kelompok yang paling rentan kesehatannya yaitu ibu hamil, ibu bersalin dan bayi pada masa perinatal. Hal ini ditandai dengan tingginya Angka Kematian Ibu (AKI). Menurut Survei Demografi Kesehatan Indonesia (SDKI) tahun 2012, AKI tahun 2007 sebesar 228/100.000 Kelahiran Hidup (KH) meningkat menjadi $359 / 100.000 \mathrm{KH}$. Penyebab langsung kematian ibu adalah faktor yang berhubungan dengan komplikasi kehamilan, persalinan dan nifas seperti perdarahan, preeklamsi/eklamsi dan infeksi. Preeklamsi merupakan gangguan multifaktorial. Beberapa penelitian memperlihatkan adanya bukti yang mendukung tentang kadar vitamin D yang berperan untuk terjadinya komplikasi kehamilan. Sumber vitamin D berasal dari sintesis endogen (matahari) dan sintesis eksogen (makanan). Sinar ultraviolet dapat mengubah pre vitamin $\mathrm{D}$ menjadi vitamin $\mathrm{D}_{3}$. Indonesia terletak didaerah tropis yang kaya akan sinar ultraviolet, tetapi masih banyak ibu hamil yang menderita preeklamsi, sehingga tujuan dari penelitian ini adalah menganalis hubungan antara kadar vitamin D dengan kejadian preeklamsi. Populasi dalam penelitian ini adalah semua ibu hamil yang di diagnosis preeklamsi dan di diagnosis hamil normal yang melakukan pemeriksaan di RSUD H.M. Rabain dan empat puskesmas di wilayah kabupaten Muara Enim. Total sampel 76 orang yang terdiri dari 38 orang kelompok kasus dan 38 orang kelompok kontrol. Rancangan penelitian dengan metode analitik yang dilakukan secara cross sectional. Analisis hasil dengan uji korelasi Point Biserial. Hasil penelitian dengan uji korelasi Point Biserial menunjukkan bahwa tidak terdapat hubungan antara kadar vitamin D dengan kejadian preeklamsi dengan nilai $\mathrm{p}$ 0,052. Simpulan dalam penelitian ini adalah tidak terdapat hubungan antara kadar vitamin D dengan kejadian preeklamsi awitan dini. Kadar vitamin D berkaitan dengan awitan lanjut pada kejadian preeklamsi yang merupakan bagian dari faktor maternal, disamping itu kejadian preeklamsi sampai saat ini dipengaruhi oleh etiopatogenesis yang kompleks.
\end{abstract}

Kata Kunci: Kadar vitamin D, kehamilan, preeklamsi

Korespondensi : Desa Ujanmas Baru kp 2 Kecamatan Ujanmas Kabupaten Muara Enim 31351, mobile 081373057550, e-mail ekadewiretnosari@gmail.com 


\begin{abstract}
Nowadays, Health Development Program in Indonesia is focusing on the priority effort to improve not only for mothers' health but also children, especially for the most vulnerable health groups, pregnant woman, maternal and infant perinatal period. It is showed from high Maternal Mortality Rate (MMR). According to the Indonesian Demographic and Health Survey (IDHS) in 2012, MMR in 2007 amounted to $228 / 100,000$ live births $(\mathrm{KH})$ increased to $359 / 100.000 \mathrm{KH}$. The direct causes of maternal death are some factors related to pregnancy complications, labor and childbirth such as hemorrhage, preeclampsia / eclampsia and infections. Preeclampsia is a multifactorial disorder. Some studies have shown the existence of evidence of vitamin D levels play a role in early pregnancy in the set of risk factors of complications. Sources of vitamin D derived from endogenous synthesis (sun light) and the synthesis of exogenous (food). Ultraviolet rays can change the pre vitamin D into vitamin $\mathrm{D}_{3}$. As Indonesian located in tropical region that is rich in ultraviolet light, but still a lot of pregnant women suffering from preeclampsia, so the purpose of this study was to analyze the relationship between vitamin D levels with the incidence of preeclampsia. The population in this study were all pregnant women diagnosed with preeclampsia and normal pregnant diagnosed performing the examination in hospitals HM Rabain and four health centers in the district of Muara Enim. Total sample were 76 respondents consisting of 38 cases and 38 controls. The study design used the analytical method conducted a cross-sectional. Analysis of the results using bivariate analysis (Corelation Point Biserial)The calculation results by using correlation Point Biserial test showed that there was no correlation between vitamin D levels with preeclampsia, p-value was 0,052 . The research shows that there is no correlation between vitamin D levels with early onset preeclampsia . Levels of vitamin D associated with late onset preeclampsia that is part of a maternal factors, in addition to the incidence of preeclampsia until today are influenced by a complex aetiopathogenesis.
\end{abstract}

Keywords: Levels of vitamin D, pregnancy, preeclampsia.

\section{Pendahuluan}

Menurut Survei Demografi Kesehatan Indonesia (SDKI) tahun 2012, AKI pada tahun 2007 sebesar 228/100.000 Kelahiran Hidup (KH) meningkat menjadi $359 / 100.000 \mathrm{KH}$. Peningkatan Angka Kematian Ibu ini berarti Indonesia mengalami keadaan yang hampir sama terhadap kesehatan ibu dan anak pada masa 15 tahun yang lalu yaitu pencapaian Angka Kematian Ibu 390/100.000 KH di tahun 1994. ${ }^{1,2}$

Faktor yang berkontribusi terhadap penyebab kematian ibu secara garis besarnya dapat dikelompokkan menjadi penyebab langsung dan penyebab tidak langsung. Penyebab langsung kematian ibu salah satunya adalah preeklamsi/eklamsi. $^{3}$ Preeklamsia adalah gangguan kehamilan yang serius yang memengaruhi hingga $8 \%$ dari kehamilan di seluruh dunia. Prevalensi dapat berkisar antara $10 \%$ sampai $18 \%$ di beberapa negara berkembang. ${ }^{4}$ Preeklamsi merupakan gangguan multifaktorial yang terjadi sebagai suatu akumulasi dari faktor-faktor yang mungkin melibatkan faktor maternal, faktor plasenta dan faktor janin. ${ }^{5}$ Kejadian preeklamsi tidak hanya menimbulkan dampak bagi kesehatan ibu hamil saja tapi juga mempunyai dampak bagi pertumbuhan dan perkembangan janin. ${ }^{6}$ Komplikasi yang di timbulkan dapat berupa keadaan akut maupun kronis.

Banyak teori yang dianut tentang penyebab preeklamsi antara lain: teori kelainan vaskularisasi plasenta, teori iskemia plasenta, radikal bebas, dan disfungsi endotel, teori imunologik, teori genetik, teori defisiensi gizi, dan teori inflamasi. ${ }^{5,7}$ Walaupun demikian yang menjadi dasar pencetus untuk patogenesis dari preeklamsi adalah kerusakan yang berhubungan dengan plasenta. Hampir semua ahli sepakat bahwa vasospasme merupakan awal preeklamsi. ${ }^{8}$

Faktor immunologik diduga berperan terhadap kejadian hipertensi dalam kehamilan. Pada preeklamsi plasenta menunjukan respon inflamasi yang kuat dan terjadinya peningkatan dalam aktivitas sistem immunologi. Hal ini menyatakan bahwa sistem immunomodulasi vitamin D secara potensial memberikan manfaat terhadap implantasi plasenta selama kehamilan. ${ }^{9-}$

11 Kecukupan akan pemenuhan kebutuhan 
vitamin D memberikan efek imunomodulasi dan regulasi tekanan darah. ${ }^{12,13}$

Penelitian yang dilakukan oleh Dror DK, dkk memperlihatkan adanya bukti yang mendukung tentang kadar vitamin D yang berperan pada bagian awal dari kehamilan didalam mengatur faktor risiko dari komplikasi dalam kehamilan, menyokong pertumbuhan janin, perkembangan tulang dan kematangan immun. ${ }^{14}$ Hasil studi yang dilakukan oleh Caroline Lechteemann, dkk menunjukkan adanya perbedaan yang bermakna rata- rata kadar vitamin D antara ibu hamil preeklamsi $(18,2 \pm 20 \mathrm{ng} / \mathrm{ml})$ dengan ibu hamil normal $(33,3 \pm 27,3 \mathrm{ng} / \mathrm{dl})$. Selain itu perbedaan rata-rata kadar vitamin $D$ terlihat juga pada perubahan musim yaitu pada musim dingin. ${ }^{15} \mathrm{Hal}$ ini dikarenakan ibu-ibu tersebut kekurangan sinar ultraviolet dari sinar matahari. Sinar ultraviolet dapat mengubah pre vitamin D menjadi vitamin $\mathrm{D}_{3}$

Deteksi dini preeklamsi dilakukan dengan berbagai pemeriksaaan tanda biologis, biofisik dan biokimia sebelum timbulnya gejala klinis sindrom preeklamsi. ${ }^{8}$ Hal ini diupayakan dengan mengidentifikasi kehamilan risiko tinggi dan mencegah pengobatan dalam rangka menurunkan komplikasi penyakit dan kematian melalui modifikasi Ante Natal Care (ANC). Tantangan terbesar dalam kebidanan modern saat ini adalah melakukan identifikasi awal dari kehamilan Hasil Tabel 1.Karakteristik Subjek penelitian dengan risiko tinggi untuk awal terjadinya preeklamsi dan melakukan tindakan yang dibutuhkan untuk memperbaiki plasenta serta menurunkan prevalensi dari penyakit ini. ${ }^{16}$

\section{Metode}

Penelitian ini dirancang dengan metode analitik yang dilakukan secara cross sectional Populasi dalam penelitian ini adalah semua ibu hamil yang didiagnosis preeklamsi dan didiagnosis hamil normal yang melakukan pemeriksaan di RSUD H.M. Rabain dan empat puskesmas di wilayah kabupaten Muara Enim. Total sampel 76 orang yang terdiri dari 38 orang kelompok kasus dan 38 orang kelompok kontrol.Kriteria inklusi untuk kelompok kasus yaitu ibu hamil tunggal janin hidup usia kehamilan 20-34 minggu dengan preeklamsi tanpa disertai penyakit lain, memiliki rekam medik yang lengkap sejak trimester pertama, dan bersedia menjadi responden. Kriteria inklusi untuk kelompok kontrol yaitu, ibu hamil tunggal janin hidup usia kehamilan 20-34 minggu; tanpa adanya komplikasi kehamilan, memiliki rekam medik yang lengkap sejak trimester, bersedi amenjadi responden. Kriteria eksklusi untuk kelompok kasus dan kontrol yaitu, Saat peneliti mengambil data dari rumah sakit / puskesmas ibu hamil dengan preeklamsi dan ibu hamil normal tidak hadir/ datang.

\begin{tabular}{|c|c|c|c|c|c|c|c|c|}
\hline \multicolumn{2}{|c|}{ Karakteristik } & \multicolumn{4}{|c|}{ Kelompok } & \multirow{2}{*}{\multicolumn{2}{|c|}{ Total }} & \multirow{3}{*}{ Nilai $\mathbf{p}^{*}$} \\
\hline & & \multicolumn{2}{|c|}{ Preeklamsi } & \multicolumn{2}{|c|}{ Normal } & & & \\
\hline & & $\mathbf{N}$ & $\%$ & $\mathbf{N}$ & $\%$ & $\mathbf{n}$ & $\%$ & \\
\hline Usia ibu & 20 - 35 tahun & 24 & 43,6 & 31 & 56,4 & 55 & 100,0 & 0,073 \\
\hline & $<20>35$ tahun & 14 & 66,7 & 7 & 33,3 & 21 & 100,0 & \\
\hline Paritas & 0 & 10 & 55,6 & 8 & 44,4 & 18 & 100,0 & 0,589 \\
\hline & $>1$ & 28 & 48,3 & 30 & 51,7 & 58 & 100,0 & \\
\hline IMT sebelum & Tidak obesitas & 25 & 45,5 & 30 & 54,5 & 55 & 100,0 & 0,200 \\
\hline & Obesitas & 13 & 61,9 & 8 & 38,1 & 21 & 100,0 & \\
\hline Total & & 38 & 50,0 & 38 & 50,0 & 76 & 100,0 & \\
\hline
\end{tabular}

Keterangan : *) Uji Chi-kuadrat

Berdasarkan usia ibu dari dari 55 orang responden yang berusia 20-35 tahun, 24 orang diantaranya adalah ibu hamil dengan preeklamsi dan 31 orang diantaranya adalah ibu hamil normal. Ini berarti bahwa lebih dari separuh responden dari masing-masing kelompok berada 
pada usia 20-35 tahun.Sedangkan untuk usia $<20$ tahun atau $>35$ tahun terdapat 21 orang responden yang terdiri dari 14 orang diantaranya ibu hamil dengan preeklamsi dan 7 orang diantaranya adalah ibu hamil normal. Pada karakteristik paritas, dari 18 respoden yang belum pernah melahirkan (nullipara), 10 orang diantaranya adalah ibu hamil dengan preeklamsi dan 8 orang diantaranya adalah ibu hamil normal. Untuk kelompok responden yang sudah pernah melahirkan $>1$ kali terdapat 58 responden yang terdiri dari 28 orang diantaranya adalah ibu hamil dengan preeklamsi dan 30 orang diantaranya adalah ibu hamil normal. Karakteristik IMT sebelum hamil, dari 55 orang responden yang tidak obesitas, 25 orang diantaranya adalah ibu hamil dengan preeklamsi dan 30 orang ibu hamil normal. Sedangkan pada kategori obesitas dari kedua kelompok terdapat 21 orang responden yang obesitas, 13 diantaranya adalah ibu hamil dengan preeklamsi dan 8 orang diantaranya adalah ibu hamil normal.

Berdasarkan hasil uji statistik karakteristik responden yaitu usia ibu, paritas dan IMT sebelum hamil, menunjukkan tidak terdapat perbedaan pada kedua kelompok dengan nilai $\mathrm{p}>$ 0,05 sehingga karakteristik kedua kelompok penelitian ini homogen.

Tabel 2. Kadar vitamin D antara ibu hamil preeklamsi dan ibu hamil normal

\begin{tabular}{lll}
\hline & \multicolumn{2}{c}{ Kelompok } \\
\cline { 2 - 3 } & Preeklamsi & Normal \\
\hline Rata-Rata & 18,04 & 20,85 \\
\hline Standar Deviasi & 6,34 & 6,04 \\
\hline
\end{tabular}

Dari tabel tersebut terlihat bahwa rata-rata kadar vitamin D pada ibu hamil preeklamsi sebesar 18,04 ng/ml sedangkan pada ibu hamil normal rata-rata kadar vitamin D sebesar 20,85 $\mathrm{ng} / \mathrm{ml}$.

\section{Tabel 3. Korelasi antara kadar vitamin D dengan kejadian preeklamsi}

\section{Kelompok}

\begin{tabular}{ccc}
\hline Kadar Vitamin D & $\mathrm{R}$ & 0,224 \\
& $\mathrm{P}$ & 0,052 \\
& $\mathrm{~N}$ & 76 \\
\hline
\end{tabular}

Uji korelasi Pearson
Dari tabel tersebut terlihat nilai bahwa $p>0,05(p=0,52)$ sehingga menunjukan bahwa tidak terdapat hubungan antara kadar vitamin D dengan kejadian preeklamasi.

\section{Pembahasan}

Pada kehamilan normal terjadi peningkatan kadar vitamin D mulai dari awal kehamilan dan akan terus meningkat seiring tuanya kehamilan bahkan akan terjadi peningkatan dua kali lipat pada trimester ketiga. ${ }^{11}$ Peningkatan kadar vitamin $\mathrm{D}$ berfungsi untuk metabolisme tulang, immunomodulasi, regulasi tekanan darah dan pemeliharaan sekresi insulin dengan sel beta pancreas penghasil insulin. ${ }^{13,17}$

Hasil dari pemeriksaan kadar vitamin D antara kedua kelompok dalam penelitian ini didapatkan hasil bahwa perbedaan rata-rata kadar vitamin D antara ibu hamil preeklamsi dan ibu hamil normal tidak jauh berbeda. Rata- rata kadar vitamin D pada ibu hamil preeklamsi yaitu 18,04 ng/ml sedangkan pada ibu hamil normal $20,85 \mathrm{ng} / \mathrm{ml}$. Selisih rata-rata kadar vitamin D dari kedua kelompok tersebut adalah $2,81 \mathrm{ng} / \mathrm{ml}(15,5 \%)$.

Walaupun rata-rata kadar vitamin D antara ibu hamil preeklamsi dan ibu hamil normal pada penelitian ini tidak berbeda, tetapi berdasarkan klasifikasi status vitamin D terdapat perbedaan pada tingkatannya. Pada kelompok ibu hamil normal dengan rata-rata kadar vitamin D 20,85 $\mathrm{ng} / \mathrm{ml}$ berada pada kategori ringan (mild deficiency), sedangkan untuk kelompok ibu hamil preeklamsi dengan rata-rata kadar vitamin $\mathrm{D}$ $18,04 \mathrm{ng} / \mathrm{ml}$ berada pada kategori sedang (moderat deficiency).

Berdasarkan klasifikasi status vitamin D, untuk kelompok ibu hamil preeklamsi dengan kategori normal sebanyak 2 orang $(5,26 \%)$, kategori ringan 12 orang $(31,6 \%)$, kategori sedang 21 orang $(55,26 \%)$ dan kategori berat 3 orang $(8 \%)$. Sedangkan pada kelompok ibu hamil normal untuk klasifikasi status vitamin D pada kategori normal sebanyak 3 orang (8\%), kategori ringan 19 orang $(50 \%)$, kategori sedang 15 orang $(39 \%)$ dan kategori berat 1 orang $(3 \%)$.

Hasil penelitian ini berbeda dengan penelitian yang dilakukan Caroline, dkk bahwa terdapat perbedaan rata-rata kadar vitamin D antara ibu hamil preeklamsi maupun ibu hamil normal dan perbedaan rata-rata kadar vitamin $D$ terlihat juga pada perubahan musim. ${ }^{15}$ Pada musim panas ratarata kadar vitamin $\mathrm{D}$ ibu hamil preeklamsi sebesar $18,21 \mathrm{ng} / \mathrm{ml}$ sedangkan pada ibu hamil 
normal sebesar 33,3 ng/ml. Selisih rata-rata kadar vitamin D antara dua kelompok pada musim panas yaitu 15, $09 \mathrm{ng} / \mathrm{ml}$ (82,9\%).Pada musim dingin rata-rata kadar vitamin $\mathrm{D}$ ibu hamil preeklamsi yaitu 17,6 $\mathrm{ng} / \mathrm{ml}$ sedangkan pada ibu hamil normal 19,5 $\mathrm{ng} / \mathrm{ml}$. Selisih rata-rata kadar vitamin $\mathrm{D}$ antara dua kelompok pada musim dingin ini adalah $1,9 \mathrm{ng} / \mathrm{ml}(10,7 \%)$.

Berdasarkan perbedaan rata-rata kadar vitamin D dari kedua penelitian diatas terlihat bahwa selisih rata-rata kadar vitamin D yang terlalu dekat antara kedua kelompok menyebabkan tidak terdapat perbedaan rata-rata kadar vitamin D antara ibu hamil preeklamsi dan ibu hamil normal.Selisih rata-rata kadar vitamin D pada penelitian ini tidak jauh berbeda dengan selisih rata -rata kadar vitamin D di musim dingin. Pada musim dingin rata-rata kadar vitamin $\mathrm{D}$ menurun di karenakan kekurangan paparan sinar matahari.

Sinar matahari merupakan sumber utama vitamin D yang paling baik. Sinar UVB yang berasal dari matahari akan diserap oleh kulit dan kemudian mengubah 7-dehidrokolesterol di kulit menjadi previtamin $D_{3}$ yang selanjutnya secara spontan dikonversikan menjadi vitamin $\mathrm{D}_{3}$ (kolekasiferol). Vitamin D ini mengalami hidrolisis, hidrolisis yang pertama terjadi dalam hati dalam bentuk $25(\mathrm{OH}) \mathrm{D}$ selanjutnya hidrolisis yang kedua terjadi di dalam dan diluar ginjal dalam bentuk $1,25(\mathrm{OH}) 2 \mathrm{D} .{ }^{9}$

Paparan sinar matahari pada negara tertentu menentukan konsentrasi kadar vitamin D pada ibu hamil, tetapi hal ini tidak berlaku bagi masyarakat Indonesia yang tinggal di daerah tropis kaya sinar matahari. Hal ini ditunjukkan oleh rendahnya kadar vitamin D pada ibu hamil baik yang mengalami preeklamsi maupun ibu hamil normal.

Intensitas sinar UVB pada waktu antara 1 jam sebelum dan 1 jam setelah tengah hari mencapai nilai tertinggi dalam satu hari. Intesitas sinar matahari UVB adalah rendah pada pukul 07.00 pagi , meningkat pada jam-jam berikutnya sampai dengan pukul 11.00. Setelah pukul 11.00 intensitas ini akan semakin relatif stabil dan tinggi sampai dengan pukul 14.00 untuk kemudian menurun pada pukul 16.00 yang intensitasnya sama dengan pukul 07.00 dengan waktu pajanan yang dibutuhkan selama 15 menit. ${ }^{18-20}$

Sebagian besar masyarakat merasa tidak nyaman untuk berada di luar rumah pada pukul 08.00-14.00. Mereka lebih banyak menghabiskan waktunya pada jam-jam tersebut di rumah atau di kantor. Selain merasa tidak nyaman, pada saat keluar rumah pun mereka menggunakan pelindung sinar matahari. Paparan sinar matahari dianggap dapat merusak struktur integritas dari kulit, perubahan terhadap warna kulit bahkan dapat meningkatkan risiko terkena kanker kulit. Dua perilaku tersebut berdampak pada terhalangnya manfaat sinar matahari dalam sintesis metabolisme vitamin $\mathrm{D}$.

Selain paparan sinar matahari, faktor lain yang berisiko terhadap rendahnya kadar vitamin D adalah kegemukan. Kegemukan maupun obesitas memberikan pengaruh terhadap metabolisme vitamin D. Hal ini dikarenakan terjadinya penurunan bioavaibilitas vitamin $\mathrm{D}_{3}$ dari kulit dan adanya deposisi di lemak yang menyebabkan vitamin D terperangkap dalam lemak dan tidak dapat dengan mudah untuk keluar. Sintesis vitamin $\mathrm{D}$ juga tergantung dari tipe kulit, tipe kulit memengaruhi keadaan melamin. Menurut Fitzpatrick, Clasification Skin Scale penduduk Indonesia adalah tipe kulit IV. Tipe kulit IV adalah jenis kulit selalu menjadi coklat tapi tak pernah terbakar karena lebih banyak mengandung melanin, berbeda dengan tipe kulit III sering menjadi coklat kadang-kadang kulit terbakar. Melanin bersifat sebagai tabir surya alami yang dapat memengaruhi penyerapan sinar matahari, sehingga hal ini dapat menurunkan efisiensi dari fotosintesis prekolekasiferol (previtamin $\mathrm{D}_{3}$ ). Faktor lain yang juga berkontribusi dalam sintesis vitamin D adalah kecukupan akan asupan vitamin D. Asupan ini dapat dipengaruhi oleh pola makan sebelum dilakukan pemeriksaan kadar vitamin D.

Kekurangan kadar vitamin D pada ibu hamil tidak hanya memberikan dampak yang merugikan bagi ibu hamil saja, tetapi juga memberikan dampak bagi janin. Kadar vitamin D yang rendah pada ibu hamil dapat menyebabkan rendahnya konsentrasi mineral tulang, kegagalan keseimbangan glukosa dan juga dapat terjadi pelunakan tulang tengkorak yang disebabkan karena kegagalan perkembangan tulang didalam uterus serta kekurangan kadar vitamin D dapat menyebabkan kelahiran preterm. Hal ini sebagai akibat dari pengaruh peran regulasi vitamin $\mathrm{D}$ di dalam tubuh sebagai anti inflamasi dan immunomodulasi yang dapat menekan produksi inflamatori sitokin.

Tidak terdapatnya perbedaan rata-rata kadar vitamin D pada ibu hamil preeklamsi dan ibu 
hamil normal memunjukkan tidak terdapatnya hubungan antara kadar vitamin D dengan kejadian preeklamsi. Terbukti pada hasil uji statistik dengan menggunakan uji Korelasi Pearson diperoleh nilai $\mathrm{p}$ 0,052 yang berarti bahwa tidak terdapat hubungan antara kadar vitamin D dengan kejadian preeklamsi. Koefisien korelasi didapatkan nilai 0,224 menunjukan bahwa keeratan hubungan antara kadar vitamin D dengan kejadian preeklamsi adalah lemah. Hal ini berkaitan dengan waktu kejadian (onset) preeklamsi yaitu awitan dini (early onset preeclampsia) dan awitan lanjut (late onset preeclampsia) ${ }^{8}$

Awitan dini terjadinya gejala klinis preeklamsi sebelum kehamilan 34 minggu sedangkan awitan lanjut terjadinya gejala klinis preeklamsi setelah kehamilan 34 minggu. ${ }^{8,21}$ Awitan dini berhubungan dengan tidak adekuatnya invasi trofoblast dari arteri spiralis ibu, perubahan aliran darah kedalam arteri spiralis dasar plasenta (placental bed), peningkatan resistensi perifer dari pembuluh darah plasenta sehingga hal ini menjadi salah satu penyebab tidak normalnya aliran darah dari arteri umbilikal. Oleh karena itu awitan dini terkait dengan faktor plasenta sedangkan awitan lanjut berhubungan dengan faktor maternal. ${ }^{21,22}$

Konsep dari maternal fetal (paternal) maladaptasi imunologik menjadi implikasi umum sebagai penyebab preeklamsi. Implantasi fetoplasenta ke permukaan miometrium membutuhkan beberapa elemen yaitu toleransi immunologik antara fetoplasenta dan maternal, pertumbuhan trofoblas yang akan melakukan invasi kedalam lumen arteri spiralis dan pembentukan sistem pertahanan imun. ${ }^{23}$

Komponen fetoplasenta yang melakukan invasi ke miometrium melalui arteri spiralis secara imunologik akan menimbulkan dampak adaptasi dan mal adaptasi yang sangat penting dalam proses kehamilan. Dampak adaptasi menyebabkan tidak terjadi penolakan hasil konsepsi yang bersifat asing, hal ini disebabkan karena adanya HLA-G berperan penting dalam modulasi sistem imun. Adanya HLA-G pada plasenta dapat melindungi trofoblas janin dari lisis oleh sel natural Killer (NK) ibu dan mempermudah invasi sel trofoblas ke jaringan desidua ibu. Sebaliknya pada plasenta hipertensi dalam kehamilan terjadi penurunan HLA-G yang kemungkinan akan memyebabkan terjadinya maladaptasi.
Maladaptasi diikuti dengan peningkatan rasio sel $\mathrm{T}$ yaitu Thelper $1 /$ Thelper 2 menyebabkan peningkatan produksi sitokin proinflamasi. Pada sel Thelper1 menyebabkan peningkatan $\mathrm{TNF}_{\alpha}$ dan peningkatan $\mathrm{INF}_{\mathrm{y}}$ sedangkan pada Thelper 2 menyebabkan peningkatan IL-6 dan penurunan $\mathrm{TGF}_{\mathrm{B} 1}$. Peningkatan inflamasi sitokin menyebabkan hipoksia plasenta sehingga hal ini akan membebaskan zat-zat toksis beredar dalam sirkulasi darah ibu yang akan menyebabkan terjadinya stress oksidatif.

Stress oksidatif bersamaan dengan zat toksis yang beredar dapat merangsang terjadinya kerusakan pada sel pembuluh darah yang disebut disfungsi endotel. Mekanisme kerusakan sel endotel dihubungkan dengan berbagai faktor. Salah satu faktornya adalah status kadar vitamin D pada ibu hamil. Vitamin D dibawa dari ibu ke janin melalui bentuk aktif $1,25(\mathrm{OH}) 2 \mathrm{D}$. Bentuk aktif 1,25 (OH)2D ini terjadi setelah mengalami hidrolisis di dalam ginjal. Kerusakan sel pembuluh darah pada plasenta dan ginjal menyebabkan kegagalan sintesis dari 1,25 $(\mathrm{OH}) 2 \mathrm{D}$ sehingga menghasilkan efek biologi berupa regulasi tekanan darah. Regulasi tekanan darah berhubungan dengan sistem renin angiotensin. Renin bekerja secara enzimatik pada protein plasma yang menyebabkan pembentukan angiotensin I dan angiotensin II yang memberikan pengaruh vasokonstriksi yang sangat kuat sehingga menyebabkan terjadinya peningkatan tekanan darah. Tahap ini merupakan tahap klinik (tahap 2) dari etiopatogenesis preeklamsi.

Kadar vitamin D ibu hamil preeklamsi dan ibu hamil normal pada penelitian ini berada dalam kategori rendah. Pengukuran kadar vitamin D ini merupakan pengukuran terhadap faktor maternal yang berkaitan dengan awitan lanjut dari kejadian preeklamsi. Pada penelitian ini pengukuran kadar vit D pada ibu hamil dengan usia kehamilan <34 minggu, sehingga penelitian ini tidak dapat mengukur faktor maternal. Hal ini tampak dari hasil uji statistik dan diperkuat dengan etiopatogenesis, menunjukkan bahwa tidak terdapat hubungan antara kadar vitamin D dengan kejadian preeklamsi awitan dini.

Dengan demikian, perlu dilakukan pemeriksaan kadar vitamin D yang dimulai pada saat awal kehamilan / trimester I sehingga dapat dilihat profil analisis kadar vitamin D yang dapat menyebabkan preeklamsi. 


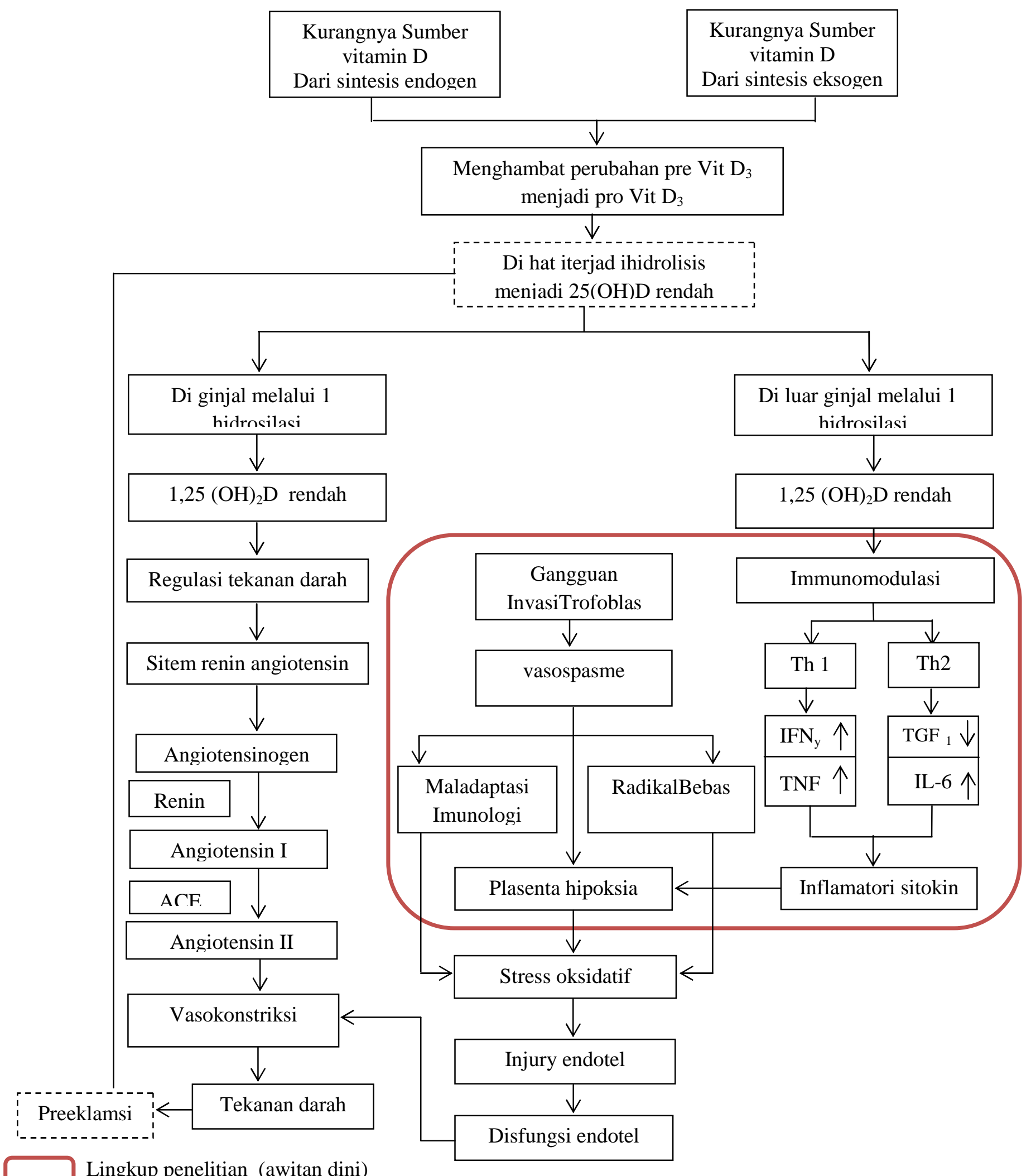

Gambar 1 Ruang LingkupPenelitian 


\section{Simpulan}

Simpulan dalam penelitian ini adalah tidak terdapat hubungan antara kadar vitamin D dengan kejadian preeklamsi awitan dini. Kadar vitamin D berkaitan dengan awitan lanjut pada kejadian preeklamsi yang merupakan bagian dari faktor maternal, disamping itu kejadian preeklamsi sampai saat ini dipengaruhi oleh etiopatogenesis yang kompleks.

\section{Daftar Pustaka}

1. Kemenkes. Pemantauan Wilayah Setempat Kesehatan Ibu dan Anak (PWS - KIA). Jakarta: Direktorat Jenderal Kesehatan Masyarakat Direktorat Bina Kesehatan Ibu; 2009.

2. Swasono Edi T. Angka Kematian Ibu (AKI) Melonjak , Indonesia Mundur 15 Tahun Prakarsa Policy. 2013:1-4.

3. Kemenkes. Pedoman Pelayanan Antenatal Terpadu. Kedua ed. Jakarta: Direktorat Jenderal Bina Gizi dan KIA RI; 2012.

4. Bezerra Sammy ML, Murthi Padma. Preventive Of Preeclampsia. Journal Of Pregnancy. 2012:9.

5. Cunningham FG LK, Bloom SL, Hauth JC, Rouse DJ, Spong CY. Williams Obstetric 23 ed. New York 2010.

6. Williams Paula ML. The Role of Genetics in Pre-eclampsia and Potensial Pharmacogenomic Interventions. Pharmacogenomics and personalized Medicine. 2012;5:37-51.

7. Erna S. Kadar Lipid Peroksida pada Kehamilan Normotensi dan Preeklamsi. Majalah obstetri dan Ginekologi. 2012:65-71.

8. Martaadisoebrata D WF, Effendi J. Obstetri Patologi Jakarta: EGC; 2013.

9. Dawodu Adekunie AH. Vitamin D Nutrition in Pregnant :Current Opinion. International Journal of Women's Health. 2013;3(5):333-43.

10. Uwe G. Mikronutrien. Jakarta: EGC; 2013.

11. Elina H. Vitamin D For The Prevention of Preeclampsia? A Hypothesis. Nutrition. 2005:225-32.

12. Cynthia A. Vitamin D and The Immune System. Investing Med. 2011;6:881-6.
13. LaMarca Babbette RJM, Granger P.Joey. Pathophysiology of Hypertension During Preeclampsia: Role of Inflamatory Cytokines. 2007:69-74.

14. Dror K.Daphna KCJ, Fung B.Ellen. Evidence of Association Between Feto-Maternal Vitamin D Status, Cord Parathyroid Hormone and BoneSpecific Alkaline Phosphatase, and Newborn Whole Body Mineral Content. Journal Nutrients. 2012;4:68-77.

15. Lechtermann Carolin hB, herman Ralf, Schundein Michael. Maternal Vitamin D status in Preeclampsia: Seasonal Change Are Not Influenced by Placental Gene Expression of Vitamin D Metabolizing Enzymes. Plos One. 2014;9(8):1-7.

16. Poon N. Early Prediction of Preeclampsia. Obstetrics and Gyneacology International. 2014:11.

17. Ajabshir Sahat AA, Nayer Ali. The Effect of Vitamin D on the Renin Angiotensin System. Journal of Nephropathology. 2014;3:41-3.

18. Kaushal manila MN. Vitamin D in Pregnancy: A Metabolic Outlook. Indian journal of Endocrinologi and Metabolism. 2013;17(1).

19. setiati S. pengaruh pajanan sinar ultraviolet B bersumber dari sinar matahari terhadap konsentrasi vitamin $\mathrm{D}(25(\mathrm{OH}) \mathrm{D})$ dan hormon paratiroid pada perempuan usia lanjut Indonesia. Kesehatan Masyarakat Nasional. 2008;2:147-53.

20. Michael H. Sunlight and vitamin D for bon health and prevention of autoimmune diseases, cancers and cardiovascular disease. American Society for clinical nutritions. 2004:1678-88.

21. Huppertz. Placenta Origins of Preeclampsia Challenging the Current Hypothesis. American Hearth Association. 2008:970-5.

22. Kuc Sylwia KM, Franx Arie, Schlelen Peter, Visser. Maternal Characteristics, Means Arterial Pressure and Serum Makers in Early Prediction of Preeclampsis. Plos One. 2013;8(5):1-8.

23. Bounds Kelsey RK. Four Pathway Involving Innate Immunity in the Pathogenesis of Preeclampsia. Cardiovascular Medicine. 2015;2. 